\title{
Representation of Buddhism Teachings in the Show Sound of Borobudur: The Reconstruction of Karmawibhangga Relief in the Age of Hyperreality
}

\author{
Nicholas Ferdeta Lakusa ${ }^{1, *}$ A.M. Susilo Pradoko ${ }^{2}$ \\ ${ }^{I}$ Graduate School of Arts Education, Yogyakarta State University, Yogyakarta 55281, Indonesia \\ ${ }^{2}$ Faculty of Languages and Arts, Yogyakarta State University, Yogyakarta 55281, Indonesia \\ *Corresponding author. Email: nicholasferdeta.2019@student.uny.ac.id
}

\begin{abstract}
The musical reconstruction work of the 9th century through the Karmawibhangga relief represents Indonesian ancient culture which contains Buddhism teachings. This study aimed to identify the meaning of the Buddhist way of life teachings in the arts and its role in the age of hyperreality. This study was a qualitative descriptive study using the semiotics data analysis method in interpreting the existing relief into the reconstruction work. The semiotics analysis theory used is one by Charles Sanders Pierce, which groups the signs based on ground, object, and interpretant. The data collection technique used includes in-dept interviews and literature studies on book, journals, and videos. The research data validity was tested using the circular quality scheme. The research findings reveal that the reconstruction work of the Karmawibhangga relief contains meanings of the Buddhism core teachings on the way of life. This can be seen from the sign system, including the visuals, the songs, and the texts in the work. The good values in the work can be used to educate the public on how to face the hyperreality age.
\end{abstract}

Keywords: Buddhism, reconstruction of the Karmawibhangga relief, semiotics

\section{INTRODUCTION}

Borobudur is a site of high historical value which belongs to the people of Indonesia. Borobudur is derived from two words, namely "bara" and "budur." Bara is originated from the Sanskrit word of "vihara", which means a temple complex, and "budur", from the Balinese word of "beduhur", meaning above [1]. Another opinion from Bhargava states that the name Borobudur was first noted by Sir Thomas Raffles in his book, The History of Java [2]. In addition to the book, there has not been many texts found which mention the name Borobudur. The only ancient manuscript which mentions the Buddhist sacred monument is the Negarakretagama by Mpu Prapanca in 1365. This temple is located in the Magelang Regency, Central Java. Borobudur was recognized by UNESCO as one of the world heritage sites in the World Herritage List number 592 year 1991. The largest Buddhist temple was estimated to be built in the 9th century, during the ruling of the Syailendra dynasty. The estimation was based on the comparison on the similarities of characters in the Karmawibhangga relief and 9th centuries inscriptions
[3]. After it was rediscovered in 1814 with the hill-like site condition full of large trees and wild bushes, Borobudur was slowly cleaned beginning in 1973 and fully restored into its final form by UNESCO in 1983. The Borobudur temple site consists of three levels of kamadhatu, rupadhatu, and arupadhatu. These levels depict the journey of human life in seeking enlightenment. The kamadhatu level of Borobudur illustrates the worldly desires in the Karmawibhangga relief. The relief tells the laws of cause-and-effect in human life.

The greatness of Borobudur is what prompts the idea of reconstructing the musical instruments in the Karmawibhangga relief. Despite the current rapid advancements of technology, information, and communication in the post-modern age, in reality there are still many artists that are intrigued to work with old, even ancient works of art. By using the existing advancements, artists are encouraged to express a fantastical idea into something that is adjacent to reality which is then believed by the public. Nevertheless, in the post-modern era, something that is considered new today can be quickly replaced by others. Unreal and real 
things continue to mix, that the boundaries between them become blurry [4]. This is what is called as a hyperreality. This age also influences the development of the arts. Post-modernism contains traits that are against the former era which put the emphasis on media instead of substance, possibility instead of certainly, and fictions instead of facts [5]. The truth of the art becomes vague, as what should be meaningful and valuable becomes a mere unique and interesting piece of art.

The reconstruction effort is realized through a study of visual signing on the Karmawibhangga relief, writing the songs, and finished with a show. In the series of programs in the Borobudur Cultural Feast, there is a session called Sound of Borobudur. In line with the name, the show aims to recreate the sounds of the musical instruments, in which the physical forms are taken from the Karmawibhangga relief. As mentioned before, the Karmawibhangga shows the depiction of human life. On the relief, bad deeds such as killing animals, abortion, robbery, laziness, being intoxicated, and sexual acts are shown. In addition to the bad deeds, however, the relief also depicts good deeds such as cleaning sacred buildings, showing examples of how to do worship in sacred sites, stopping a fight, protecting children, etc. [6]. Ali Gardy Rukmana, a young artist from the city of Situbondo, East Java, was trusted by the Nusantara Village Net o team, in recreating three string musical instruments into the physical forms, in which the shapes can be seen in the Karmawibhangga relief number 102, 125, and 151. The Padma Swargantara composition is one of the songs created as the final product of the Karmawibhangga relief reconstruction. Ali Gardy plays the flute and gasona (relief 101), Redy Eko Prastyo plays Solawa (a string instrument from relief number 51), Rayhan Sudrajat plays Gasola (relief number 125), John Arief plays kendang (relief number 1), Agus Wayan Joko Prihatin plays the recreation of string instruments made by Ali Gardy, and Trie Utami on vocal.

As a cultural heritage that becomes the spotlight in the world, the creative process of the musical reconstruction of the 9th century music of the Karmawibhangga relief should be accompanied with a preliminary study. This is because there is a concern that the work will only be accepted by the public as a current sensation with no meaning. A preliminary study is expected to be used as a reference of the reconstruction process, involving the Buddhis musical culture in the 9th century, ancient manuscripts, as well as the depiction of the atmosphere when the music is played. This is all necessary for the sake of the accuracy of the musical piece. In addition, there needs to be a study of signs or art semiotics in the development process as it is related with the conformity between the interpretation and understanding of the Buddhist community in the 9th century and the reconstructing artists. Therefore, this paper analyzes the signing system using the Charles Sander Pierce theory on the reconstruction of the Karmawibhangga string instruments from the perspective of Buddhism life lessons.

\section{LITERATURE REVIEW}

\subsection{Charles Sanders Pierce's Semiotics}

Semiotics is derived from the Greek word semeion which means "signs" [7]. This discipline studies all that is related with signs, such as the sign system and the use of signs. Semiotics can be used to analyze media and cultural forms through methods development by semiotic figures. Semiotics analysis examines the ways of understanding by relating certain texts and their interaction with a culture or signing system which exist on the signs [8].

The Charless Sanders Pierce theory was selected to analyze this reconstruction work. Pierce groups his semiotics theory into three main elements, namely the triangle of meaning. This triangle unravels meaning that is presented as a sign when used to communicate. The three main elements include: (1) Sign, a physical form which can be sensed and refers to something outside the sign itself; (2) Sign Reference (object), the object to which the sign refers; and (3) Interpretant, the idea of an individual in using the sign within a meaning [9]. The object can be divided into 3 classifications, namely icon (sign with similar forms with the original object), index (related to a cause-and-effect sign), and symbol (sign which has a relation with the signifier and signifier of the signified) [10]. Icon is related with entities in the world, while index puts icon based on space and time. The study of signs with Peirce's semiotics is very appropriate to dissect hidden meanings in the work because through Peirce's semiotics there is a complete classification of the relation of objects, representations, and interpretations. The unity of these three things will provide an accurate interpretation of the artist's sign, so that people can understand the true essence of musical values in relief through the work of Sound of Borobudur.

\subsection{The 9th Century Musical Reconstruction of the Karmawibhangga Relief}

Reconstruction is the return of something into its original place, assembling, or redrawing the existing materials to be assembled back into the original event [11]. The process or rebuilding or recreating needs to be done with accurate organization based on the reconstructed object [12].

In this study, the reconstructed object is the Karmawibhangga relief. Relief refers to an illustration of folklores or religious teachings. The bottom relief of the Borobudur temple is called Kamadhatu/ 
Karmawibhangga. The Karmawibhangga relief contains illustrations on human behaviors and the consequences of those behaviors, as well as punishment they will get in the afterlife.

There are two ways to obtain meaning from literary texts and reliefs, namely by identifying the event in one scene and the identity of the illustrated object or figure [13]. When both of these aspects are well understood, the illustration of the atmosphere of the environment will give a sense of completeness in the analysis.

Prior to the influence of India, the nation of Indonesia already had a high musical tradition. At the time, the developing musical instruments included nekara, kendang, kecer, and kemanak. The influence of Indian culture results in the addition of several instruments, including vina (a guitar with three strings) and the harp [14].

In addition to the knowledge on the musical development in Indonesia at the time, the Karmawibhangga relief also shows that music had existed at the time. In the reconstruction process of the Karmawibhangga relief, Ali Gardy learns the visual proportion of the instruments on the relief compared to the people holding the instruments. The instrument was made of teak wood which at least has to be eighty years old. The following figure is the comparison of the Karmawibhangga relief and the reconstructed musical instruments.

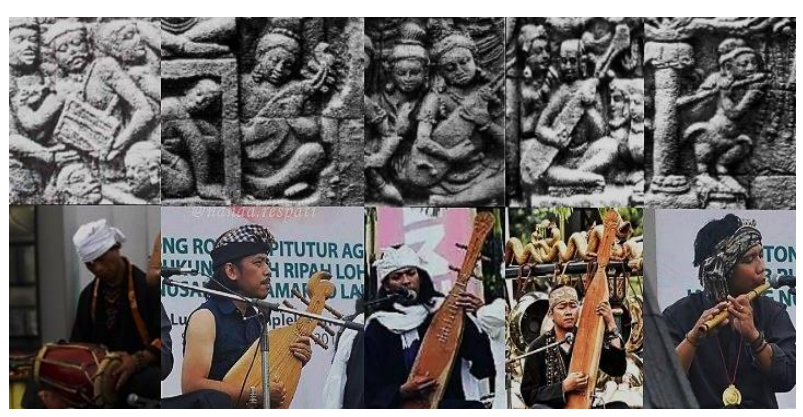

Figure 1 The comparison of the musical instruments in the relief and the reconstructed version

Musical instruments whose shapes are sculpted in Karmawibhangga relief numbers 1, 101, 102, 125, and 151 are reconstructed into their present form as shown in Figure 1. In order from left to right the instruments used can be seen in Figure 1, namely the drum, solawa, gasola, gasona, and flute respectively.

\subsection{Buddhism Life Lessons}

Buddhism learning is so ingrained to its believers that it is called Buddhist philosophy. This can be understood from Aburaera's writings which say that Buddhists understand religion in a philosophical way [15]. The three main themes of thought that are important in Buddhist philosophy are harmony, tolerance and humanity. Harmony between humans, humans and nature, and humans and heaven. Tolerance implies that there is openness to different opinions, including in matters of religion. Humans are basically good, so humans must seek happiness in this world by interacting with others and also nature. Emmanuel explained in more detail his insight that Buddhist philosophy refers to the view or application of the Buddha's goodness teachings on the values of life, existence, knowledge, reason, and human morality in a fundamental way [16].

\section{RESEARCH METHODOLOGY}

This research used the qualitative approach with a descriptive qualitative type. Descriptive qualitative research aims to reveal a particular problem or situation as it is so that it can provide an accurate picture of the actual state of the object under investigation in order to solve certain specific problems [17]. The method used to analyze was Charles Sanders Pierce's semiotics with sign classification based on ground, object, and interpretant. The data collection techniques used were in-depth interviews and literature study of data from books, journals, and videos. The validity of the research data was obtained with a circular pattern that goes in a circle by constantly repeating and comparing the subject of the research through field evidence, documents, and interviews [18].

Data collection was carried out by in-depth interviews with the reconstruction artists, i.e. Ali Gardy Rukmana as the musical instrument craftsman, Redy Eko Prasetyo as the chairman of Kampung Nusantara Network, as well as the Borobudur Conservation Center, An archaeologist, Dwi Cahyono, and the Mendut temple monks. In addition, data was obtained from documentation of reconstruction work when they were performed. The research is limited to extracting signs in the Sound of Borobudur that can be interpreted to face the era of hyper-reality.

\section{FINDINGS}

The musical sign system is auditory, but to reach the listeners, the music composers present their creation through musicians in the form of a written sign system or visual sign [19]. The message contained in a musical piece will be received slightly differently or even very differently by the audience. The appropriateness of the use of musical elements and expressions in playing the music will be very important. The writing of symbols on musical scores is used to convey the messages the composer wants to present in his or her work. In this case, the 9th century society left the relief to be used as a cultural "hard drive." 
The reconstruction result is a song entitled "Padma Swargantara" which has three main parts of A, B, and $\mathrm{C}$, as seen in Figure 2.

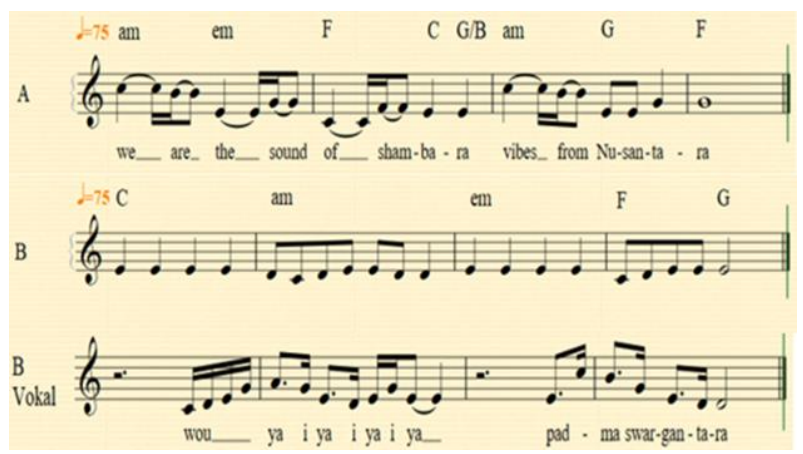

Figure 2 Musical transcript of the main melodic notations

Part $\mathrm{C}$ of the song was not transcribed to give the opportunity for improvisation. The part of the song mentioned is a part of one or several lyrics with a convincing closure [20].

The following are the results of Pierce's semiotic analysis from the reconstruction of the 9th century music in the Karmawibhangga relief.

The first sign analyzed is the lotus carving on the head of gasola and gasona.

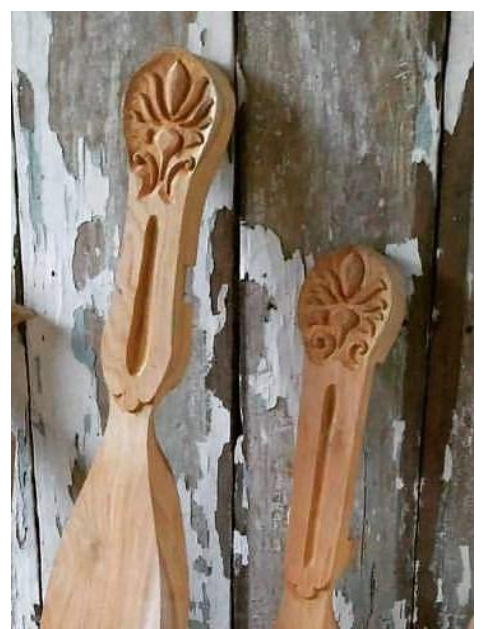

Figure 3 Lotus carving on the head of gasola and gasona

The Buddhism teachings are represented in the physical form of the head of gasona and gasola.

The lotus carving sign is a Buddhism religious instrument (symbol). This instrument is used for Buddhism religious worship or rituals. The lotus flower represents purity for the Buddhists, a sacred altar to listen to the inner voice or conscience. This means that the instruments are used in the Buddhism religious rituals [21]. In addition, the musical piece also represents sacredness and purity.

Next, sign is present in the number of strings in three instruments. Solawa has 5 strings, gasola has 4 strings, and gasona has 2 strings. The number of strings represent teachings that must be "played" or applied in life. The relief illustrates how gasona is used as the musical instrument played in heaven. The instrument has 2 strings, which represents the two-way relationship between God and humans, while the 5 strings symbolize Buddhism main teachings or the Buddhism Pancasila on the teaching to condemn murder, theft, improper behavior and speech, and intoxication [22]. On the other hand, the 4 strings are aimed to convey the four life truths on Dukkha (sorrow) as mentioned by Bhikkhu Nanamoli and Bhikkhu Bodhi as a framework of the entire Buddhism teaching aimed to understand life for all humans regardless the ethnicity, race, or religion [23].

Another sign in the reconstruction work is the use of teak wood as the main material for making the Karmawibhangga instruments. The native wood of Indonesia that is strong and resilient in all weathers. The artist wants to emphasize that the reconstruction work is an original culture of Indonesia which will be continuously preserved across generations. This notion is represented by the high-quality nature of the teak wood, and the teak tree, which is native to Indonesia.

The title of the piece, "Padma Swargantara", represents certain meanings. This symbolized Buddhism in Indonesia. Padma is another name for the lotus flower, which is used by Buddha to describe purity, while Swargantara refers to heaven. The sign contained in the song refers to a norm and symbol due to the natural relationship between the signifier and signified. The sign gives a reason for the relationship between signifier and signified in a direct manner. The title of the song means that the entire effort of the musical reconstruction of the Karmawibhangga relief is ultimately about Buddhism teachings which is closely related to the historical development of the Nusantara music. The artists who work on this piece imagine that the music represents the 'sound' of Borobudur. In other words, this piece attempts to recreate the atmosphere or recording of the community life, religiosity, and musical existence of the 9th century. The gotong royong philosophy is reflected from the role of each instrument in one musical piece.

The string instrument was chosen to represent the Buddha's teachings contained in the Mahavastu II book which uses string imagery to convey teachings about life that must be lived with the right portion. It's like the strings that have to be pulled at the right tightness to produce a beautiful tone. A string that is pulled too tight will break, but if it is too loose, it will not sound 
beautifully. This means that humans must not overdo it and also should not be lazy in doing something.

The musical expression is spirited, optimistic, and sacred. The minor chord progression in Part A provides a spiritual experience that is peaceful and mindful to the listeners, and the atmosphere is incredibly moving. Such feeling is incited through instruments with a soft timbre and the glissando technique, which can bring the listeners to a meditative atmosphere. The chord progression in Part B is designed to express a sense of optimism as reflected by the I chord which is a strong foundation of a musical piece. Moreover, the optimism is also reflected from the lyrics which proudly declare that "We are the sound of Shambara, vibes of Nusantara." In acting, the line can be depicted as looking up and starry eyes for being proud of the cultural treasure that is Shambara (Borobudur). The sense of optimism is also strengthened by accent or stress on certain notes and the main melody of the vocals accompanied by gasola. Part $\mathrm{C}$ represents another scene in the relief where music is not only used for religious activities, but also as a form of entertainment. Part $\mathrm{C}$ of the reconstruction work shows the joy of the community. The rhythm of the music turns lively, inviting the audience to dance. This is clearly presented in Relief 125 which describes Anak Garuda and Mahojaskasmavadhana (the authority) enjoying the entertainment of music using gasola and other instruments. The transition from part $\mathrm{A}$ to $\mathrm{C}$ has a different basic note to give the impression of a drastic and climatic change of scenes. Self control on pleasure is also evident in this piece, where the gratitude shown by the lively music turns back to the calmer part A. This means that the personal enjoyment of music should not be excessive and in vain, but directed to gratitude and the spirit of moving on to preserve good values. Part B has a religious atmosphere and is used as a closing to the song, referring to the end of life that must be accounted for before God. According to a book published by the Borobudur conservation agency, the flute, solawa, and gasona in Relief 101, 151, and 102 are a depiction of a musical performance in heaven (svarggah) [6], as indicated by the presence of heavenly creatures, the inscription of svargga, the sacred buildings, the monks, and the god. The flute in the musical reconstruction gives the effects of beauty, tenderness, eternal happiness, and sacredness, while gasona and solawa provides the Buddhist religious tone in the musical piece of Padma Swargantara. The order of play begins with rhythmic tones of kendang (drums), followed by the flute, the Karmawibhangga three string instruments, and other musical combination. Kendang is used to start the music based on the order of the relief, where kendang shows up in Relief 1 as a means to attract people's attention in the crowd in the busy market to give an announcement. The order of the music represents the order of life and the wheel of life in which human experiences petty to complex problems, but still manages to proceed in harmony.

\section{DISCUSSION}

Ward (in Pradoko) in fact notes that art in the postmodern age challenges the notion of art in the modern era as an activity to define oneself, that is by proposing that that art is the interpretation of social activities and complex social relationships [18]. The concern of artists in art and cultural activities in this era is that there are still art activities with the assumption that art is merely considered as a money-generating commodity, so that in the process, there is no depth as it is based only on assumptions without legitimate supporting facts. The post-modern era is a critical effort of the failure of the modern era which causes negative impacts on the moral life, sense of humanity, environmental aspects, and aesthetics. Because of this, the arts created in the postmodern era must be able to recover the humanity values that were corrupted in the modern age. When this is ignored, problems on the bifurcation between the fake and real reality believed by the society will spread and even take roots. In the post-modern era, a work of art has values of virtuous teachings in life based on Buddha's teachings which can serve as a weapon against the influence of hyperreality. These values are implied, yet can also be explicitly found in musical instruments and songs written. These works can serve as a means for the moral and spiritual education of the society, just as the lotus flower carved on the head of gasona that teaches the sacredness of life and the number of strings on the instrument which reflects the core teachings of Buddhism. By understanding the signs, it is hoped that tolerance among the diverse society toward ethnicity, religion, race, and groups may improve, so that they will have a strong stand against rumors concerning ethnic groups, religions or races. The important values contained in this work can also be seen from the use of the teak wood material on the instruments and song titles. Against hyperreality, the distinctness of the teak wood as the Indonesian original wood, in addition to song titles which mean the Buddhist legacy in Indonesia should restore the society that experiences an identity crisis or the sense of shame toward its own culture. The musical experience obtained from this work can be integrated in the curriculum in the age of individualism in the popular culture in order to preserve the traditional norms, so that a nationalist and patriotic education can be developed while simultaneously giving appreciation toward the global culture to facilitate multiculturalism and social harmony [24]. Along with the growth of hyperreality among the society, there are negative views on how the Karmawibhangga relief is assumed as a relief which illustrates the human passions, including lust. For this reason, this work attempts to prove that the Karwawibhangga relief does not only expose the human 
desires, but also warning on the consequences of bad deeds, the examples of good deeds, and their rewards.

\section{CONCLUSION}

Based on the observation and semiotic analysis, it can be concluded that the reconstruction work of the 9th century music in the Karmawibhangga relief contains Buddhism teachings and way of life which play an important role for humans against hyperreality. This can be learned from the signing of the materials used, carvings on the musical instruments, the number of strings, and the songs written. The teachings on the way of life found in the details of the work represent the combination of Indonesian and Buddhist cultural values. The distinct feature of the Indonesian art culture which is identical with the ontological scope of catharsis and self-purification is present in this work. The Buddhism way of life involves good deeds, tolerance, and humanity, allowing this work to have a universal sense against hyperreality.

\section{REFERENCES}

[1] Hidayat, Komaruddin, and Putut Widjanarko. Reinventing Indonesia: menemukan kembali masa depan bangsa [Reinventing Indonesia: Rediscovering the Future of the Nation]. Jakarta: Mizan Publika, 2008.

[2] Bhargava, P. Borobudur Stupa: A Devotional Song in The Stone. Proceedings of the Indian History Congress. Indian History Congress, 2009. pp. 1246-1247.

[3] Tanudirjo, Daud A. Changing perspectives on the relationship between heritage, landscape and local communities: A lesson from Borobudur. terra australis 36(5), 2013. pp. 65-81. URL: https://library.oapen.org/bitstream/handle/20.500.1 2657/33513/462201.pdf?sequence=1\#page=77

[4] Wiryanti, Sri. Iklan dan Hiper-realitas Perempuan [Advertising and Women's Hyper-reality]. Nirmana 6(2), 2004. pp. 158-170. URL: https://ojs.petra.ac.id/ojsnew2/index.php/dkv/articl e/view/16339

[5] Alistiana, Lisa. Kebenaran Seni dalam Konteks Postmodern [The Truth of Art in a Postmodern Context]. Discovery: Jurnal Ilmu Pengetahuan $3(1)$, 2018.

URL: http://czd57.com/index.php/discovery/article/view/ 239

[6] Santiko, Haryani, and D. S. Nugrahani. Adegan dan Ajaran Hukum Karma pada Relief Karmawibhangga [Scenes and Teachings of the
Law of Karma on Karmawibhangga Relief]. Balai Konservasi Borobudur, 2012.

[7] Lantowa, Jafar, Nila Mega Marahayu, and Muhammad Khairussibyan. Semiotika: Teori, Metode, dan Penerapannya dalam Penelitian Sastra [Semiotics: Theory, Methods, and Its Application in Literary Research]. Yogyakarta: Deepublish, 2017.

[8] Stokes, Jane. How to do media and cultural studies: Panduan untuk melaksanakan penelitian dalam kajian media dan budaya [How to do media and cultural studies: A guide to conducting research in media and cultural studies]. Yogyakarta: Bentang Pustaka, 2006.

[9] Kriyantono, Rachmat. Teknik Praktis Riset Komunikasi [Practical Techniques for Communication Research]. Jakarta: Kencana Prenamedia Group, 2006.

[10] Liliweri, Alo. Serba Ada Serba Makna [All Meanings, All Available]. Jakarta: Kencana, 2011.

[11] Efendi, Jonaedi. Rekonstruksi Dasar Pertimbangan Hukum Hakim [Reconstruction of Judges' Legal Considerations]. Depok: Prenadamedia Group, 2018.

[12] Syamsudin. Konstruksi Baru Budaya Hukum Hakim Berbasis Hukum Progresif [New Construction of Progressive Law-Based Judge Law Culture]. Jakarta: Kencana, 2012.

[13] Nastiti, Titi Surti. Perempuan Jawa: Kedudukannya dan Peranannya dalam Masyarakat Jawa Abad VIII-XV [Javanese Women: Position and Role in Javanese Society in the VIII-XV Century]. Bandung: PT Dunia Pustaka Jaya, 2016.

[14] Waluyo, et al. Ilmu Pengetahuan Sosial [Social Sciences]. Jakarta: PT Intan Pariwara, 2008.

[15] Aburaera, S, Muhadar, and Maskun. Filsafat Hukum: Teori dan Praktik [Philosophy of Law: Theory and Practice]. Jakarta: Kencana, 2013.

[16] Emmanuel, Steven. A Companion to Buddist Philosophy. Malden: Wiley-Blackwell, 2013.

[17] Kimbal, R. W. Modal Sosial dan Ekonomi Industri Kecil: Sebuah Studi Kualitatif [Social Capital and the Economy of Small Industry: A Qualitative Study]. Yogyakarta: Deepublish, 2015.

[18] Pradoko, Susilo. Paradigma Metode Penelitian Kualitatif: Keilmuan Seni, Humaniora, dan Budaya [Paradigm of Qualitative Research Methods: Scientific Arts, Humanities, and Culture]. Yogyakarta: UNY Press, 2017. 
[19] Kurniawati, Erna. Video Musik Sabyan Gambus "Atouna El Toufoule" Studi Analisis Semiotika Charles Sanders Peirce [Music Video of Sabyan Gambus "Atouna El Toufoule" Charles Sanders Peirce's Semiotic Analysis Study]. AlMUNZIR 12(1), 2019. pp. 97-120. DOI: dx.doi.org/10.31332/am.v12i1.1281

[20] Prier, Karl-edmund. Ilmu Bentuk Musik [Music Form Science]. Yogyakarta: Pusat Musik Liturgi, 2015.

[21] Suwendra, I Wayan. Bunga Rampai Pendidikan Karakter Model Agama Hindu [Rampai Flower Character Education Model Hinduism]. Bandung: Nilacakra, 2018.

[22] Setiawan, I. S., \& Hidayat, E.A. Dialog Antar Umat Beragama sebagai Piranti Menumbuhkan Sikap Toleransi [Inter-Religious Dialogue as a Way to Foster Tolerance Attitudes]. Al-Mada 1(1), 2018. pp. 60-77. DOI: doi.org/10.31538/almada.v1i1.142

[23] Nanamoli \& Bodhi. Majjhima Nikaya: Khothbahkhothbah Menengah Sang Buddha [Majjhima Nikaya: The Intermediate Sermons of the Buddha]. Jakarta: Dhammacitta Press, 2013.

[24] Ho, Wai-Chung. Moral education in China's music education: Development and challenges. International Journal of Music Education 28(1), 2010. pp. 71-87. DOI: doi.org/10.1177\%2F0255761409351351 